\title{
EDITORIAL
}

\section{The ambition of the European Respiratory Journal}

\author{
Marc Humbert*,\#,
}

Cr ounterculture icon Timothy Leary once said: "Women who seek to be equal with men lack ambition" [1]. As incoming Chief Editor of the European Respiratory Journal $(E R J)$, I will bluntly state that the ambition of the Journal is not to seek to be equal with other respiratory publications but to be the best possible publication available to help, inform and open new horizons to junior and established healthcare professionals and scientists who have an interest in (respiratory) medicine and science.

\section{THE FLAGSHIP}

The ERJ is proud to be the flagship publication of the European Respiratory Society (ERS), an undisputed leading group of international clinicians and scientists [2, 3]. After 4 years' service on the Editorial Board of previous Chief Editors Anh Tuan Dinh-Xuan and Vito Brusasco, I know that being the new Chief Editor of the Journal will be a difficult but exciting challenge $[3,4]$. On this occasion, I would like to briefly share some facts and thoughts with you in this opening editorial.

\section{IMPACT FACTOR}

Despite obvious limitations [5], it is now widely accepted that having the best possible impact factor (and by association, being ranked in the top journals in the field of respiratory medicine) is important for our authors and readers. There is no doubt that the previous Chief Editors of the Journal performed very well and that our current impact factor is good (fig. 1). However, our aim is to significantly improve this impact factor over the coming years. To this end, we will lobby for submission of the best manuscripts to the Journal and be even more selective in our editorial decisions. The number of articles published per year will therefore decrease so that we are able to publish the best possible material in our pages.

\section{REJECTION RATES}

The attractiveness of the Journal and the excellent output of the international respiratory community have led to a steady increase in manuscript submissions, which has doubled in the last decade (fig. 2). In such circumstances, our rejection rate has sharply increased. This may disappoint some authors but it is the price to pay to publish high-quality manuscripts in the Journal. It is therefore likely that around $90 \%$ of original submissions will not be accepted for publication in the next

*Univ. Paris-Sud, Faculté de Médicine, and ${ }^{\# A P-H P}$, Service de Pneumologie, DHU Thorax Innovation, Hôpital Bicêtre, Le Kremlin-Bicêtre, and "INSERM U999, Centre Chirurgical MarieLannelongue, LabEx LERMIT, Le Plessis-Robinson, France.

CORRESPONDENCE: M. Humbert, Service de Pneumologie, Hôpital Bicêtre, Assistance Publique Hôpitaux de Paris, 78 rue du Général Leclerc, 94270 Le Kremlin Bicêtre, France. E-mail: marc.humbert@bct.aphp.fr few years. In order to provide more space to our authors, we will attempt to publish more letters and correspondence on original findings and debates. This forum will be ambitious and it should allow many of us to present original findings in the best possible scientific environment. In addition, we will offer some authors the opportunity to resubmit their work to the European Respiratory Review (ERR). The ERR is another high-quality publication of the ERS, led by a new Chief Editor Professor Vincent Cottin, who is also a well-known and highly respected Associate Editor of the ERJ [3, 6-8].

\section{INTERNATIONAL BY NATURE}

The Journal is proud to be European-born, but it is international by nature [3]. Our readership and authorship are now represented all over the world and we have recognised this in our new Editorial Board of established and rising leaders from the five continents. As an example of our broadening readership, in 2012 , only $35 \%$ of our online readers originated from Europe, while the USA, Asia, South America, Oceania and Africa represented $30 \%, 23 \%, 5 \%, 5 \%$ and $2 \%$, respectively. These figures are constantly changing and it is my pleasure to witness growing ERJ influence in more and more developing countries [9-11].

\section{NEW SECTIONS}

Original respiratory science and medicine will remain our priority [9-13]. We will launch new sections in the coming few months in order to challenge our environment. Art will also be welcome in the Journal and we are currently discussing how to regularly include this in our pages; this should lead to a "from

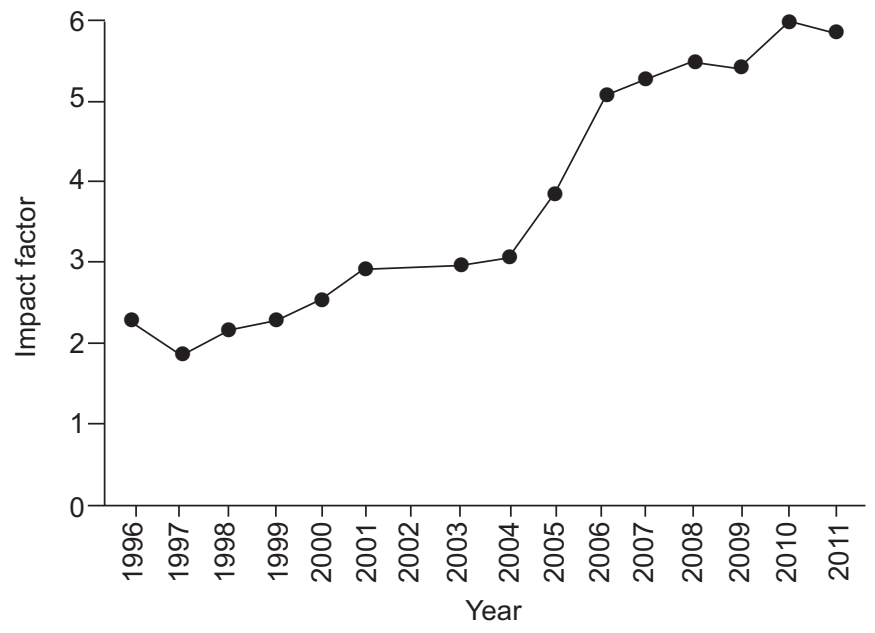

FIGURE 1. European Respiratory Journal impact factor, 1996-2011. Reproduced and modified from [4]. 


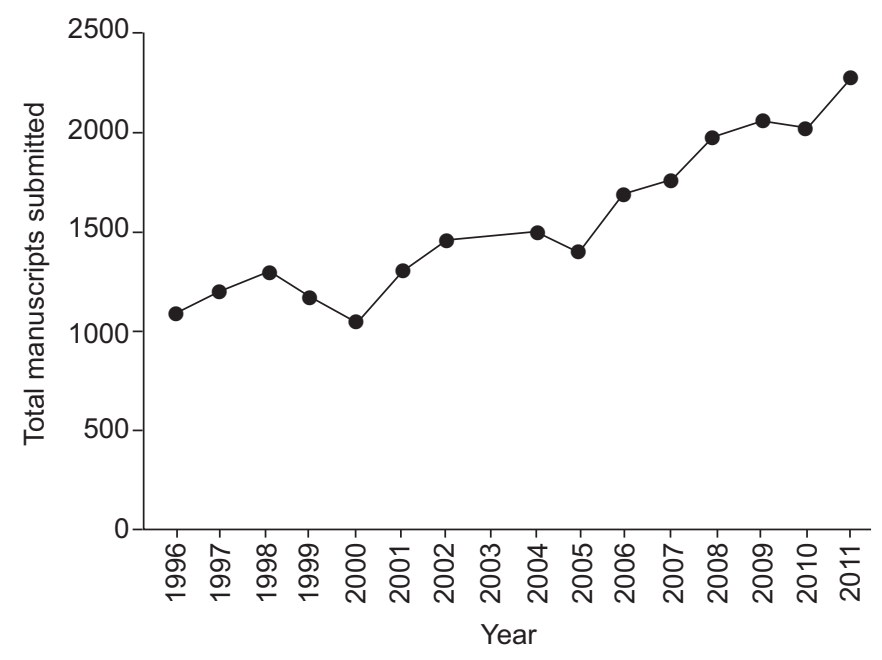

FIGURE 2. Total manuscripts submitted to the European Respiratory Journal, 1996-2011. Reproduced and modified from [4].

the museum" section. Similarly, emerging concepts in physiology, immunology, biology, and experimental medicine and surgery will be welcome in the Journal, with a "lungstorming" section allowing cutting-edge knowledge to be presented to our community in a pleasing fashion.

We are proud to count amongst our Editorial Board highly respected international advisers and editors who truly lead the way in many fields of medicine. These colleagues will select high-quality reviews to be included in state-of-the-art manuscripts, as well as in sharp and snappy editorials, commentaries, news and views and pro-con debates.

\section{THE AMBITION OF THE FLAGSHIP}

I hope you will enjoy the coming issues of the Journal, both during this transition period and beyond. The transition between the last editorial team and the new one will be very smooth, thanks to the friendly collaboration we have established with our outgoing Chief Editor and incoming Deputy Editor, Professor Anh Tuan Dinh-Xuan, who kindly agreed to stay on board the flagship. Together with an outstanding group of Associate Editors, International Advisors and members of the
Editorial Board, we will try to produce the best possible scientific publication. Being ambitious is certainly our trademark but we will never forget that our first goal is to serve our community and do the best we can to provide our readership with the most accurate and updated information.

The very substance of the ambitious is merely the shadow of a dream.

Shakespeare, Hamlet, Act II, Scene ii

\section{STATEMENT OF INTEREST}

A statement of interest for M. Humbert can be found at www.erj. ersjournals.com/site/misc/statements.xhtml

\section{REFERENCES}

1 Timothy Leary. http://en.wikiquote.org/wiki/Timothy_Leary. Date last modified: May 1, 2012. Date last accessed: November 10, 2012.

2 Siafakas NM. The European Respiratory Society, 1990-2010: a 20year anniversary story of success. Eur Respir J 2010; 35: 1-2.

3 Dinh-Xuan AT, Brusasco V, Wedzicha JA, et al. ERS publications: the flagship and the fleet. Eur Respir J 2012; 40: 535-537.

4 Dinh-Xuan AT, Brusasco V. The editors' farewell and confident look back to the future. Eur Respir J 2012; 40: 1309-1311.

5 Brusasco V, Dinh-Xuan AT, Leff AR, et al. Impact factor and its role in academic promotion. Eur Respir J 2009; 34: 1499-500.

6 Humbert M. Introducing the new European Respiratory Review. Eur Respir J 2009; 33: 466-467.

7 Humbert M. Update on the European Respiratory Review. Eur Respir J 2010; 36: 993-994.

8 Humbert M. You say goodbye, and I say hello!. Eur Respir Rev 2012; 21: 265-266.

9 Fonseca GHH, Souza R, Salemi VMC, et al. Pulmonary hypertension diagnosed by right heart catheterisation in sickle cell disease. Eur Respir J 2012; 39: 112-118.

10 Zhang Y, Li N, Zhang Y, et al. Clinical analysis of 76 patients pathologically diagnosed with pulmonary cryptococcosis. Eur Respir J 2012; 40: 1191-1200.

11 Balabanova Y, Radiulyte B, Davidaviciene E, et al. Risk factors for drug-resistant tuberculosis patients in Lithuania, 2002-2008. Eur Respir J 2012; 39: 1266-1269.

12 Soriano JB, Brusasco V, Dinh-Xuan AT. The European Respiratory Journal makes COPD a priority. Eur Respir J 2011; 38: 999-1001.

13 Humbert M, Simonneau G, Dinh-Xuan AT. Whistleblowers. Eur Respir J 2011; 38: 510-511. 